\title{
The story of a father about the circumstances experienced in a Neonatal Intensive Care Unit
}

\author{
The story below was written by a father. It is about his experience, feelings and reflections after \\ several months of having his twins hospitalized: a boy and a girl who were born extremely preterm. \\ These reflections were written in the context of the First National Meeting on Humanism in \\ Medicine, organized by the Sociedad Argentina de Pediatría in April 2013. Both parents were invited \\ to participate in a session called "What patients tell us".
}

What can a father add to a story told by a mother? My wife and I have talked for months about the story of our children and of Helena's passing. I use the term "passing" as going into another form of being (or not being). Or towards the recognition of solidarity between the living and the dead, and the strange ways of recalling and conversing. My wife has told a beautiful story about Helena's epic experience in this world, about her staying by our side until she decided to finally let go, about her delicate and precise whisper, which sounded like the last chord of an overture. We just showed our respect for her inexorable will.

What does a father know? What can a father say? It is said that fathers do not have such a deep bond with their children. Our babies do not even have our family name while in their hospital cribs; it is only when they are officially registered that the law admits them into our descent. Fatherhood seems to be an administrative or putative matter, a symbolic investiture, whereas motherhood is a natural fact. While such society-given nature ties mothers to their children's cribs as if they were a substitution of their wombs, fathers remain in a limbo until the law recognizes them such right. When children are hospitalized, fathers remain adrift, with no direction in a sea of desolation. Our children do not carry our names; they were born too prematurely and they struggle in a cruel purgatory that is neither a womb nor life.

Little is expected of fathers with respect to their children. At most, we have to perform meticulous tasks with clumsiness worthy of gentlemen, but it is always mothers who are called in as connoisseurs of their children; they are endowed with abnegation and maternal wisdom. It is also mothers who are required to make a sacrifice and the ones more harshly judged. However, fathers also know about our children. The mother, giving birth in an untimely manner, is alienated, taking care of her children within a stage that reproduces a disrupted natural order: incubators, parenteral feeding, mechanical lactation; technology as a necessary but grotesque surrogate. The father, standing in the halls or undaunted, close to his children, swallows the anguish or escapes from reality in a sort of dignified manner. But fathers, in that barren nowhere awaiting for luck or calamity, is also aware.

Many do not know that they know, others think they do not know, others say they do not know as much as mothers. Left aside, until fortune makes its call, sometimes fathers are capable of perceiving things in all their crude reality and do not know how to voice them.

What does a father know about his children? He knows about their ancestors: about their grandparents, great-grandparents, the family history and their good fortune and hard times, wars, exile and losses. He also knows about hopes and wishes. He knows the plot into which his children are welcome. That is not to know little. Without knowing it, fathers also know about their genes and history and, above all, they know about their system of values, their material and spiritual beliefs. A father knows how to preserve his child's dignity. "Dignity" is based on thought and acceptance. Fathers should be able to "dignify" their children, even in a place where their view of the world is criticized by the dominant belief of what a father or mother "should" want. A good father knows how to honor his children's life, even if it means accepting a tragic ending and acting according to his ethical, religious and human convictions. A father should also be capable of honoring his child's death. He should be able to recognize what the limit is.

We fathers, wandering around units of neonatology, plunged into despair, can do much more than performing surrogate maternal tasks. Those who stand there next to cribs, close to our wives, should watch over the dignity, honor and 
humanity of our children, whichever meaning each mother and father assigns to those words. And, if necessary, both the mother and the father should be able to preserve their children from medicine itself. At present, in many instances, healthcare teams provide tireless and thorough care to our children and sometimes they even offer comfort and support to parents, beyond what is strictly established in their jobs. Their work is invaluable. But it is only parents who are capable of seeing that child, who in many cases should not have been born yet, a child who suffers and fights, a child that only parents can call "daughter" or "son."It is only parents -and their extended family- who "suffer" for those children. It is parents whose lives are slipping away right there. Because that child means to them and their family a "daughter or son", a "sibling", a "grandchild." Because it is parents who integrate that child into their genealogy and descent and -broadly speaking-into their view of the world, with their own gods, beliefs and conceptions about life, death, and lastly, their questions about being. It is not fair to demand that medicine humanizes patients in such a way that it will lose any scientific or procedural guidance. If this happened, medicine would lose effectiveness as a discipline. It is also true that parents are not able to take an absolutely ethical position in life or death situations, and it is not an indispensable condition if they do not want to. This is just our story, our testimony. Other parents may have other stories of pain and hope that they might want to share. This testimony, which might have been or become the story of others, is unique because it is about our children and their odyssey. It is also pretty special because their "hospitalization story" ended with an unexpected final twist which was overwhelming to us all.

In our case, the difference was that we were forced to put a halt to the situation, even against our own dreams and hopes. Our daughter's final complication was merely an evidence of her ominous condition. It was bitter to acknowledge the situation. At that moment we understood what we had suspected for a long time: our daughter did not want this life, she did not want to keep fighting as we expected her to do. And suddenly, we were not surprised. Helena had lived the last three months even before she should have been born. It is such a paradoxical situation that words are not enough to express it. Was it too much to ask of her? What if she did not want to? Or was it that she could not go on? So we had to put into words what we believed she was telling us. Let me go. Then, we became her voice. There were neither disagreements nor hesitation between us. We both understood that she had reached her limit, and also that it was her will. Undoubtedly, many people thought ours was a bold and questionable action. But instead of letting our daughter in the hands of a therapy with nothing else to offer her to have a respectable future, instead of letting her become a hollow object of medical experiments, it was us who stood up for her dignity. We requested an urgent meeting with an Ethics Committee and talked before the medical team, inspired and determined. Thus, after listening to our story, the Committee studied our daughter's extremely delicate situation and admitted that it was despicable to prolong an increasingly invasive and irrelevant treatment. Sometimes, an open conversation is the most powerful medical instrument: it is this way how we recognize the "humanity" that makes us who we are and binds us to others. Humanized words are the ones which, at critical times, transcend specialists' technical jargon and link us to the irrevocable human condition and its life and death cycles. Death sets a limit to men, but it is also their most inalienable right. It was this way that we were able to release our daughter from the medical and technical almighty ties, with their miraculous promises of healing or breakthrough therapies, and see her in her most frail humanity. We were then able to offer her a precious death, and let her go.To her, our Helena, who gave us her enigmatic time in this life in her final breath.

Ours was an experience about "limits". Not just because our children were living at a breaking point since the beginning, like many other children hospitalized in neonatology units, but also because our situation confronted medicine with its own boundaries. We believe that in situations of life or death, or when there is a risk of violating human dignity, medicine as a discipline should be capable of taking a stand beyond advanced technical and scientific responses and its offer of more and better treatments for human suffering. It is neither fair nor feasible to expect medicine to give us all the answers or require it to be infallible or to promise guaranteed success. It is for this reason that, in those end stage and collapsing times, medicine 
should not fall back on a technical and scientific discourse based on causes and effects or statistics or palliative treatments; instead, medicine should embrace humanism. In such borderline cases, medicine can, and should, renounce to all claims (even social demands) of being the bearer of all answers and yield ground to reflect about life and death, human integrity or questions about the being, thus playing an essential role in the science of man.

Gastón Basile gastonjbasile@yahoo.com 